\title{
The growth rate of Nile tilapia Oreochromis niloticus fry fed on fermented Lemna sp. meal
}

\section{Laju pertumbuhan benih ikan nila Oreochromis niloticus yang diberi pakan mengandung tepung Lemna sp. fermentasi}

\author{
Rita Rostika $^{1 *}$, Yuli Andriani ${ }^{1}$, Arthur Henry Abram ${ }^{1}$, Apriana Vinasyiam² \\ ${ }^{1}$ Prodi Perikanan FPIK, Universitas Padjadjaran \\ Kampus Jatinangor, Jalan Raya Bandung Sumedang, Sumedang, Jawa Barat 45363 \\ ${ }^{2}$ Departemen Budidaya Perairan, Fakultas Perikanan dan Ilmu Kelautan, Institut Pertanian Bogor \\ Kampus IPB Dramaga Bogor, Jawa Barat 16680 \\ *E-mail: ritarostika_unpad@yahoo.com
}

\begin{abstract}
This research aimed to evaluate the supplementation of fermented Lemna sp. meal (FLM) in the artificial diet on the growth rate of Nile tilapia Oreochromis niloticus. The research design used was complete randomized design consisting of four treatments, namely A (0\% FLM), B (20\% FLM), C (30\% FLM), and D (40\% FLM), performed in triplicates. Experimental fish used was Nila tilapia at the initial size of 5-7 cm, fed with feed containing $18 \%$ protein content. The parameters observed were the nutritional composition of FLM, specific growth rate (SGR), feed conversion ratio (FCR), survival, and water quality. Fermentation with Effective Microorganism 4 (EM4) has increased crude protein and crude lipid of Lemna sp. meal, respectively, by 5.60\% and 5.76\%. However it decreased its crude fiber content down to $15.27 \%$. The result suggested that supplementation of FLM $0-40 \%$ in the artificial diet could give SGR $0.81-1.20 \%$ /day, FCR 2.48-2.97; and survival $72 \%-84 \%$ in Nile tilapia. The addition of $40 \%$ LFM showed the best result among all treatments.
\end{abstract}

Key words: Lemna meal, EM4, fermentation, Nile tilapia fry

\begin{abstract}
ABSTRAK
Tujuan dari penelitian ini adalah untuk mengevaluasi penggunaan tepung Lemna sp. fermentasi (TLF) pada pakan buatan terhadap laju pertumbuhan ikan nila Oreochromis niloticus. Rancangan penelitian yang digunakan adalah rancangan acak lengkap terdiri atas empat perlakuan, yaitu A (0\% TLF), B (20\% TLF), C (30\% TLF), dan D (40\% TLF) dengan masing-masing tiga ulangan. Ikan uji yang digunakan adalah ikan nila dengan ukuran awal 5-7 cm yang diberi pakan mengandung protein 18\%. Parameter yang diamati dalam penelitian ini adalah nilai nutrisi TLF, laju pertumbuhan spesifik (LPS) ikan nila, rasio konversi pakan (RKP), sintasan (SR), dan kualitas air. Fermentasi dengan Effective Microorganism 4 (EM4) meningkatkan protein kasar dan lemak kasar tepung Lemna sp. sebesar masing-masing 5,60\% dan 5,76\%, akan tetapi menurunkan serat kasar hingga 15,27\%. Hasil penelitian menunjukkan bahwa pemberian TLF $0-40 \%$ dalam pakan komersial menghasilkan LPS $0,81-1,20 \%$ / hari; RKP 2,48-2,97; dan kelangsungan hidup 72\%-84\%. Pemberian TLF sebanyak 40\% merupakan perlakuan yang menunjukkan hasil terbaik.
\end{abstract}

Kata kunci: tepung Lemna, EM4, fermentasi, benih ikan nila

\section{INTRODUCTION}

One of the critical success factors in aquaculture is the growth rate of the fish. The growth is defined as the increasing size, weight, and length within a certain time. Growth occurs when there is surplus input of energy and amino acids (proteins) derived from feed. Acquired energy is used for basic metabolic maintenance (i.e. respiration, specific, and dynamic action), excreted out of the body, or available as surplus energy. This excess energy afterward is allocated for gaining weight (somatic growth), gonadal maturation and reproduction, or being stored in 
muscle, liver, and mesenteric fat (McBride et al., 2015). Feed remains one of important factors in fry culture. Nutritional composition of feed given during fry rearing has a significant influence to the fish growth in the following phases.

Feeding cost in aquaculture accounts for over $50 \%$ of the total production cost (Rostika, 2009; Yousefian \& Amiri, 2009). Reducing fish meal is an important issue in the aquaculture industry because of its increased price (Lim \& Lee, 2011). Replacing the amount of fish meal in diet formulation with alternative local feed material is one of solutions (Kader et al., 2012). Fish feed components on one hand are suggested to be more affordable and not causing competition to human consumption need, while in the other hand have to contain sufficient nutrition in fine quality for fish growth.

Duckweeds are small floating aquatic plants (Talukdar et al., 2012; Kabir et al., 2009; Uddin et al., 2007). This plant may benefit for the fishery business as a chep and abundant source of feed component. Ansal et al. (2010) reported that the productivity of Lemna sp. planted in an effective planting system reach to 12-38 tons of dry weight/ ha/year. Lemna sp. has high protein content $(38 \%)$, however it also rich in crude fiber content. Unfortunately, this may inhibit the digestive and absorbing abilities in the fish's digestive system.

Effective Microorganism 4 (EM4) was a mixed culture of various beneficial microorganisms that includes fermented and synthetic microorganisms containing lactic acid, photosynthetic bacteria, Actinomycetes sp., Streptomycertes sp., yeast, and cellulose decomposing fungus (Ariyanto, 2013; Nur et al., 2016). Fermentation process using EM4 can reduce the amount of crude fiber of a feed material (Sihotang, 2012). Fermentation of Lemna meal is expected to lessen its crude fiber content thus making Lemna potential for being a fish feed compound. The aim of this study was to evaluate the supplementation of fermented Lemna meal (FLM) in commercial fish feed on the growth rate of Nile tilapia Oreochromis niloticus.

\section{MATERIALS AND METHODS}

\section{Fermented Lemna meal (FLM)}

Lemna sp. was yielded from culture pond, and sun-dried for one day. Next step was drying Lemna in an oven at the temperature of $60{ }^{\circ} \mathrm{C}$. Lemna was then formed into meal, and was analyzed for its nutritional composition (proximate analysis) based on method carried by Takeuchi (1988).
Fermentation solution was made by diluting EM4 in water at the ratio of 1:100. EM-4 used contained Lactobacillus casei, Saccharomyces cerevisiae, and Rhodopseudomonas palustris and produced by PT. Songgolangit Persada. Solution then was mixed with Lemna meal at the ratio of 3:10, and well mixed. The mixture was then stored in a plastic bag at the temperature of 29 ${ }^{\circ} \mathrm{C}$ for seven days according to method performed by Handajani (2011). Sour smell was an indicator that Lemna meal has been fermented. The FLM was then sun-dried and analyzed for its proximate composition.

FLM was added to commercial feed at a level to the treatment dose. The commercial feed produced by PT Central Pertiwi at protein content of $18 \%$ was used as experimental feed. As a binder, albumin of chicken egg was used. Mixture was then formed into pellets at suitable size for experimental fish and was sampled for proximate analysis.

\section{Fish rearing}

The experimental fish used in this study was taken from Sumedang, West Java, at the initial size of 5-7 cm. At the first step, aquariums were washed with soap and potassium permanganate (PK), and were then rinsed, and dried. Water was filled into the aquariums and was kept for several days. Experimental fish were then acclimatized in a particular tank with no feed was given for one day. The initial weight of fish was measured before they were moved into aquariums.

Fish were fed three times in a day at 06:00 am, 12:00 pm, 16:00 pm at satiation. Faeces and other waste were taken by daily siphoning. Fish weight was monitored every seven days. Water was changed every week. Fish were reared for 42 days.

\section{Research design}

Present study was conducted using complete randomized design, consisted of four treatments in three replications, as follows:

A: commercial feed (control)

B: commercial feed $80 \%$ and FLM $20 \%$

C: commercial feed $70 \%$ and FLM 30\%

D: commercial feed $60 \%$ and FLM $40 \%$

\section{Evaluating parameters}

Nutritional content of expereimental feed

Nutritional contents of FLM and experimental feed used in this experiment were obtained based on proximate analysis. 


\section{Survival}

Survival was calculated using formula as follows :

Survival $(\%)=\mathrm{Nt} /$ No $\mathrm{x} 100$

Specific growth rate

Specific growth rate of fish was counted as follows:

$\operatorname{SGR}(\% /$ day $)=(\ln \mathrm{Wt}-\ln \mathrm{Wo}) / \mathrm{t} \times 100$

\section{Feed conversion ratio}

Feed conversion ratio was measured with formula as follows:

$$
\mathrm{FCR}=\mathrm{F} /[(\mathrm{Wt}+\mathrm{D})-\mathrm{Wo}] \times 100
$$

\section{Note:}

Survival $=$ fish survival $(\%)$

$\mathrm{Nt} \quad=$ number of shrimp at the end of the experiment (individual)

No = number of shrimp at the beginning of the experiment (individual)

SGR = specific growth rate (\%/day)

$\mathrm{Wt}=$ the average weight of the fish at the end of the study (g)

Wo $=$ the average weigth of the fish at the beginning of the study $\mathrm{T}_{1}(\mathrm{~g})$

$\mathrm{t}=$ rearing period

$\mathrm{F} \quad=$ total of feed given during rearing period (g)

D = biomass of dead fish $(\mathrm{g})$

Data analysis

Data were collected from periodical samplings and analyzed using oneway ANOVA and using a statistical software SPSS 17.

\section{RESULTS AND DISCUSSION}

The process of fermentation using EM4 has caused the conversion of nutritional value of the Lemna meal involving the increase of the moisture, crude protein, and crude lipid as much as $91.15 \%, 5.60 \%$, and $5.76 \%$ respectively (Table 1). However the fermentation process decreased the ash content for $3.93 \%$ and the crude fiber at the percentage of $15.27 \%$.

The increase of crude protein level in present research was less compared to Warasto et al. (2014) that has successfully reached percentage of $60 \%$ in fermentation of kiambang Salvinia molesta with EM4. This result was predicted as caused by the difference content of EM4 and plants used. Warasto et al. (2014) used EM4 which contained photosynthetic bacteria, lactic acid bacteria, yeasts, and fungi, meanwhile EM4 this study did not contain fungi.

However similar result was found in Bairaqi et al. (2002) who has FLM with the help of Bacillus sp. A decrease in crude fiber, crude protein, and tannins content were obtained as the results. According Sitohang (2012) the different proximate compositition of a material after fermentation was caused by the activity of cellulase enzymes contained in microbs. In previous study Santoso and Aryani (2007) stated that EM4 produce large amounts of crude fiber digesting enzymes such as cellulases and mannase (Solfan \& Rosmaina, 2010; Muhakka et al., 2015).

Cellulolytic microbes using cellulose as a source of carbon and energy by producing cellulase enzymes that can break down, and degrade the cellulose component and its derivatives into glucose. Bairaqi et al. (2002) stated that fermentation of Lemna meal produces a decline in crude fiber and crude protein content by $31 \%$ and $38 \%$ respectively. This suggested that fermentation is an efective way to reduce the content of crude fiber in a plant-derived feed material.

The decrease in the ash content to $3.39 \%$ in the FLM was closely related to the decrease in the crude fiber content of the feed. The crude fiber content in the FLM reduced $15.27 \%$ as a result of the activity of the cellulose enzyme contained in Saccharomyces cereviseae (Sihotang, 2012). The

Table 1. Results from proximate analysis of fermented Lemna meal (FLM)

\begin{tabular}{cccc}
\hline Nutrient & Before fermentation $(\%)$ & After fermentation $(\%)$ & Difference $(\%)$ \\
\hline Moisture & 6.49 & 13.61 & +91.15 \\
Ash & 14.48 & 13.91 & -3.93 \\
Crude protein & 24.00 & 25.35 & +5.60 \\
Crude lipid & 7.81 & 8.26 & +5.76 \\
Crude fiber & 15.19 & 12.87 & -15.27 \\
\hline
\end{tabular}


amount of crude fat in FLM increased up to 5.76\% after fermentation. The increase of fat content was caused by the microorganism's capability to produce lipid / fat during fermentation process. Microorganisms, as other life cell systems, produce lipid or fat.

The SGR value was not influenced by the treatment of FLM (Table 2). It means that FLM could produce the same growth rate as the control feed (without supplementation of FLM) did. The most problem, a plant and algae-derived alternative feed material commonly faces are the crude fiber and anti-nutritional content (Suarez et al., 2009; Ncha et al., 2015; Suprayudi et al., 2015). There factors are the major causes for the low level of feed digestibility in fish which eventually could lower fish growth performance. Similar to this statement, Bairagi et al. (2002) proposed that factors that reduce the fish growth rate when they are fed with fermented meal content in the feed was the amount of crude fiber and other anti nutritions in the feed. It was because the fish do not have cellulose enzyme to hydrolyze the cellulose.

In analysis of FCR, no significant difference was found in all treatments (Table 2). The FCR level in this study varied from $2.48 \pm 1.91$ in treatment $\mathrm{C}$ to $5.20 \pm 2.19$ in control treatment. Even it was not markedly different with other treatments, the FCR shown in treatment control was tremendously higher than study conducted by Ayuningtyas et al. (2015) 1.53 and Vinasyiam et al. (2016) 1.72. This could be explained as the result of the lower SGR than other Nile tilapia in some studies or because of other reasons which were not further analyzed at present experiment i.e. fish appetite, feed texture and taste, slow digestion and absorption process rate in gut.

Determination of best treatment needed a further approach for instance the feed cost analysis (Table 3). Based on the mean value of feed conversion ratio, the minimal cost to produce $1 \mathrm{~kg}$ of fish was obtained in treatment $\mathrm{C}$ which was the addition of $30 \%$ FLM in commercial feed. Regarding to the feed cost analysis, it could be stated that the most efficient treatment was $\mathrm{C}$ which showed the minimum cost (Rp21,824,-) to produce the similar SGR and FCR. However treatment $\mathrm{C}$ surprisingly had the least survival (72\%) among all treatments (72-84\%) (Figure $1)$, thus making treatment $\mathrm{D}$ with feed cost Rp25,452,- and survival (77\%) became the best treatment in this study. No sufficient data was obtained to explain the reason of survival result. Further study was needed to investigate the relation of addition FLM at particular level to the mortality of fish.

\section{CONCLUSION}

Present study concluded that the fermentation of Lemna meal using EM4 reduced the content of crude fiber to $15.27 \%$, increases the crude protein to $5.6 \%$, and increases the crude fat to $5.76 \%$. The supplementary FLM to $40 \%$ in commercial feeding resulted the best treatment among all treatments because it showed the highest survival, lower feed cost, while did not

Table 2. The specific growth rate (SGR) and feed conversion ratio of Nile tilapia fry

\begin{tabular}{ccc}
\hline Treatment & Specific growth rate $(\% /$ day $)$ & Feed conversion ratio \\
\hline A & $0.81 \pm 0.13 \mathrm{a}$ & $2.97 \pm 2.19 \mathrm{a}$ \\
B & $1.20 \pm 0.48 \mathrm{a}$ & $3.15 \pm 1.04 \mathrm{a}$ \\
C & $1.10 \pm 0.58 \mathrm{a}$ & $2.48 \pm 1.91 \mathrm{a}$ \\
D & $0.83 \pm 0.60 \mathrm{a}$ & $3.03 \pm 1.76 \mathrm{a}$ \\
\hline
\end{tabular}

Note: different letter in the same column indicates significant difference.

Table 3. Feed cost analysis

\begin{tabular}{ccl}
\hline Treatment & Feed price per kg & Feed cost* \\
\hline A & Rp10,000,- & Rp29,700,- \\
B & Rp9,200,- & Rp28,980,- \\
C & Rp8,800,- & Rp21,824,- \\
D & Rp8,400,- & Rp25,452,- \\
\hline
\end{tabular}

Note: $*=$ total feed cost to produce $1 \mathrm{~kg}$ of fish based on mean value of feed conversion ratio. 


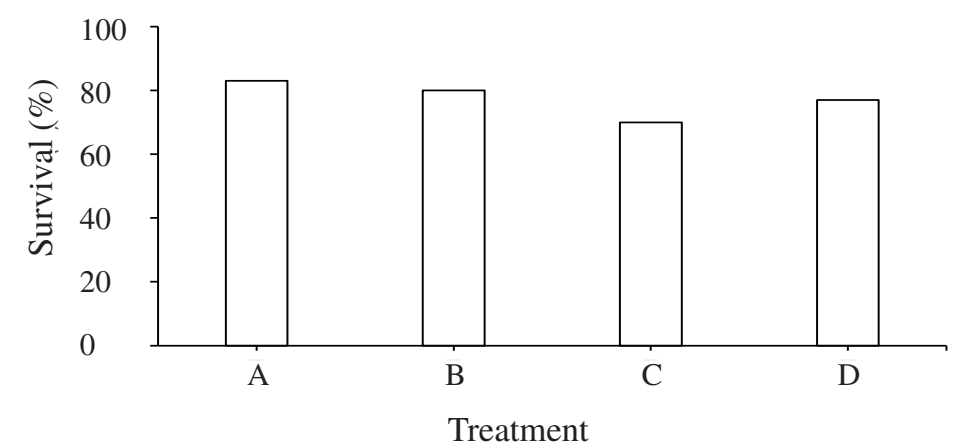

Figure 1. The average of survival Nile tilapia fry. Note: $A=0 \%$ FLM, $B=20 \%$ FLM, C=30\% FLM, and $D=40 \%$ FLM)

show significant difference of daily growth rate and feed conversion ratio from control (without fermented Lemna meal).

\section{ACKNOWLEDGEMENT}

Author would like to express gratitude to Noir Primadona Purba, S.Pi, M.Si as the academic advisor and members of counselling committee who have been a great help for the writing of this research.

\section{REFERENCES}

Ansal MD, Dhawan A, Kaur VI. 2010. Duckweed based bio-remediation of village ponds: An ecologically and economically viable integrated approach for rural development through aquaculture. Livestock Research for Rural Development 22: 130.

Ariyanto SE. 2013. Perbaikan kualitas pupuk kandang sapi dan aplikasinya pada tanaman jagung manis Zea mays saccharata Sturt. Jurnal Sains dan Teknologi 4: 164-176.

Ayuningtyas SQ, Junior MZ, Soelistyowati DS. 2015. Sex reversal of red tilapia using 17A-methyltestosterone-enriched feed and increased temperature. Jurnal Akuakultur Indonesia 14: 159-163.

Bairagi A, Ghosh KS, Sen SK, Ray AK. 2002. Duckweed Lemna polyrhiza leaf meal as a source of feedstuff in formulated diets for rohu Labeo rohita Ham. fingerlings after fermentation with a fish intestinal bacterium. Bioresource Technology 85: 17-24.

Handajani H. 2011. Optimalisasi substitusi tepung Azolla terfermentasi pada pakan ikan untuk meningkatkan produktivitas ikan nila gift. Jurnal Teknik Industri 12: 177-181.
Kabir ANMA, Hossain MA, Rahman MS. 2009. Use duckweed as feed for fishes in polyculture. Journal of Agriculture and Rural Development 7: 157-160.

Kader AM, Shunsuke K, Manabu I, Saichiro Y, Mahbuba B, Binh TN, Jian G, Asda L. 2012. Can fermented soybean meal and squid byproduct blend be used as fishmeal replacements for Japanese flouder Paralictichthys olivaceus. Aquaculture Research. 43: 1427-2438.

Lim SJ, Lee KJ. 2011. A microbial fermentation of soybean and cottonseed mea increases antioxidant activity and gossypol detoxification in diets for nile tilapia Orechromis niloticus. Journal of The World Aquaculture Society. 42: 49-503.

McBride RS, Somarakis S, Fitzhugh GR, Albert A, Yaragina NA, Wuenschel MJ, Basilone G. 2015. Energy acquisition and allocation to egg production in relation to fish reproductive strategies. Fish and Fisheries 16: 23-57.

Muhakka M, Wijaya A, Ammar M. 2015. Nutritional dried matter, crude protein and crude fiber on lowland tidal grass fermented by probiotic microorganisms for use Bali cattle feed. Animal Production 17: 24-29.

Ncha OS, Michael PB, Nnabuchi UO, Alex E. 2015. Effect of diets with Moringa leaf meal on growth, carcass composition and haematology of Clarias gariepinus. International Journal of Fisheries Aquatic Studies 3: 397-401.

Nur T, Noor AR, Elma M. 2010. Pembuatan pupuk organik cair dari sampah organik rumah tangga dengan penambahan bioaktivator EM4 (Effective Microorganisms). Konversi 5: 5-12.

Olaniyi CO, Oladunjoye IO. 2012. Replacement value of duckweed Lemna minor in Nile tilapia Oreochromis niloticus Diet. Transnational 
Journal of Science and Technology 2: 54-62.

Rostika R. 2009. Peningkatan kualitas tongkol jagung sebagai sumber karbohidrat melaui fermentasi Trichoderma viriade, Trichoderma reesei, Aspergillus oryzae, Rhizopus oligoporus dan konsorsiumnya serta efeknya terhadap peforma ikan tawes Puntius gonionitus [Disertasi]. Bandung: Universitas Padjadjaran.

Santoso U, Aryani I. 2007. Perubahan komposisi kimia daun ubi kayu yang difermentasi oleh EM4. Jurnal Sains Peternakan Indonesia 2: $53-56$.

Sihotang R. 2012. Pengaruh pemberian dedak padi hasil fermentasi ragi Saccharomyces cereviseae terhadap pertumbuhan biomassa Daphnia sp. Jurnal Perikanan dan Kelautan. 3: 65-72.

Solfan B, Rosmaina R. 2010. Pengomposan serabut buah kelapa sawit menggunakan Aspergillus terreus SUK-1 dan EM4. Jurnal Agroteknologi 1: 26-30.

Suarez JA, Gaxiola G, Mendoza R, Cadavid S, Garcia G, Alanis G, Suarez A, Faillace J, Cuzon G. 2009. Substitution of fish meal with plant protein sources and energy budget for white shrimp Litopenaeus vannamei (Boone, 1931). Aquaculture 289: 118-23.

Suprayudi MA, Inara C, Ekasari J, Priyoutomo N, Haga Y, Takeuchi T, Satoh S. 2015.
Preliminary nutritional evaluation of rubber seed and defatted rubber seed meals as plant protein sources for common carp Cyprinus carpio L. juvenile diet. Aquaculture Research. 46: 2972-2981.

Talukdar MZH, Shahjahan M, Rahman MS. 2012. Suitability of duckweed Lemna minor as feed for fish in polyculture system. International Journal of Agricultural Research, Innovation and Technology. 2: 42-46

Uddin MN, Rahman MS, Shahjahan M. 2007. Effects of duckweed Lemna minor as supplementary feed on monoculture of gift strain of tilapia Oreochromis niloticus. Progressive Agriculture18: 183-188.

Vinasyiam A, Suprayudi MA, Alimuddin. 2016. Digestive enzymes activities in Oreochromis niloticus fed diet supplemented with recombinant growth hormone. Jurnal Akuakultur Indonesia 15: 15-23.

Warasto, Yulisman, Fitrani M. 2013. Tepung kiambang Salvinia molesta terfermentasi sebagai bahan pakan ikan nila Oreochromis niloticus. Jurnal Akuakultur Rawa Indonesia 1: 173-183.

Yousefian M, Amiri MS. 2009. A review of the use of prebiotic in aquaculture for fish and shrimp. African Journal of Biotechnology 8 (25): 7313-7318. 